\title{
The Party Abroad and Its Role for National Party Politics
}

\author{
Ekaterina R. Rashkova \\ Assistant Professor, Public Governance and Management, Utrecht University \\ Utrecht, the Netherlands \\ E.Rashkova@uu.nl \\ Sam van der Staak \\ Head of Programme, Regional Europe, International IDEA, Brussels, Belgium \\ S.vanderStaak@idea.int
}

\begin{abstract}
Despite proliferating research on party politics and notable media engagement with the issues of migration and refugee flows, we know little about the existence and operation of 'the party abroad'. The latest UN migration report states that more than 270 million people reside outside their country of origin. OsCE recognizes the need for representation of varied political views as one means to maintain democratic stability within states. This study unravels the notion of the 'party abroad', develops a theoretical legal framework within which it can exist, and empirically exams parties that operate abroad. The case studies show the potential for political engagement with the diaspora, that such operations are not systematically regulated at the moment, and that parties operating abroad have different financing models. These findings, coupled with increasing migration, call for more future work on the party abroad, both by academics and by professionals.
\end{abstract}

\section{Keywords}

party abroad - diaspora - party regulation - representation 
Within the ongoing discussion on immigration in Europe, and the future integration in European societies, little attention is paid to the role of migrants' political representation in their host country or their country of origin. Given the pressing need for peace, security, and stability posed by the movement of large numbers of people around the world, this is puzzling. One manner to strengthen those is by assuring wide range of representation of different views. The right of representation is a main civil right, which has been gained by the popular adjudication to give up a set of natural, human, rights. Locke (1948) lists the rights of 'life, liberty and property' as some such fundamental natural rights. For Hobbes (1968), however, these very natural rights create the state of nature, which is theoretically a state of war of man against man. To prevent this state of nature men choose to enter into a 'social contract' by giving up certain natural rights in exchange of guaranteed civil rights by a sovereign authority - the government. Given the inherent link between the government, political parties, and citizens, it is pertinent that the latter feel represented both for legitimizing the power of those who rule, but also for preserving peace among heterogeneous preferences. This importance is recognized in the OSCE with the activities of the office for democratic institutions and human rights (ODIHR). One of the regular activities of ODIHR is the issuance of guidelines for political party regulation. The existence and frequent revision of these guidelines put political parties and their role in representation at the center of the political stage. Amongst many current developments, which attest for the large movement of people around the world, the question of who and how represents these misplaced citizens becomes crucial for the preservation of the democratic process.

In addition, in various countries, the electoral behavior of diasporas has played a key role in the success of political parties. This research studies the notion of the 'party abroad' and aims to unravel how and to what extent national political elites engage with their citizens who reside outside their country. and consider the legal treatment (or non-treatment) of the operations of political parties beyond national borders mainly offering suggestions for such based on party rules existing in the national party law. It delineates the potential functions that citizens who reside outside their nation of origin the diaspora - can have for domestic politics, and matches these with the

* This article is based on research previously published in discussion paper 1/2019 by International IDEA. 
potential goals that national political parties may have. As a result, the paper provides guidelines for practitioners on how to engage with their citizens residing abroad. The overarching question of the paper is 'How can political parties engage the diaspora in the domestic political process?' Specifically, we focus on presenting various models that political parties wishing to engage their citizens abroad can use. Imperative for making a decision is knowing what the party wants to achieve and how much time, effort, and resources it is willing to invest in reaching that goal. Using our typology and extended research, and depending on the type of diaspora different national parties are facing, they can make an informed decision about which strategy is best for them. Our study may prove more beneficial to parties in both young and established democracies, especially those with large number of citizens residing abroad. We illustrate this with short case-studies from France, Germany, Spain, Turkey, Ukraine and the United States, which have either significant experience in the operation of political parties abroad (cases of Germany and the United States) or large diasporas (case of Turkey, Ukraine) or both (Spain, France). The results from these interviews reiterate the necessity to study the operations of political parties abroad, and give examples how parties have done it or hope to do it in these countries and provide basis for further research, as well as give grounds for the legal framework proposed here. Refugees

While elections are vital to the functioning of democracies around the world, with the ever expanding effects of globalization - free trade and movement of workers, international treaties and cooperation, dependency - we observe a growing number of people residing outside their state of origin - think of expatriates, migrants, refugees - which precludes them from fully participating in the democratic process, both in their new as well as original homeland.

The operation of political parties abroad is not an entirely new phenomenon, both empirically and academically speaking. The Democrats Abroad, the official organization of the American Democratic Party, has been in operation since the 1960 and has committees in more than 42 countries throughout the world. Others - such as German, Dutch and Swedish parties - have also been involved in major international efforts abroad, not only limited to serving their own expatriates, but also, through their international foundations, assisting the development of political parties in young democracies (Burnell and Gerrits, 2010). 
The manner in which parties operate domestically, and specifically the rules, which govern their everyday conduct, has also been a point of scholarly attention in recent years. Various work has been done in establishing not only what rules govern political parties and how these shape political behaviour (van Biezen and Borz, 2012; Casal Bértoa, Piccio and Rashkova, 2014; Rashkova, 2015), but also critically examining the issue of the relation between the rules and the rule-makers, in both ends of which, can be argued, stay the political parties (Katz and Mair, 1995). Yet, most existing studies on party system development and party regulation limit themselves to the operation of political parties domestically. We hardly know anything about whether and how political parties conduct their affairs beyond national borders, to what extent do these vary between countries, and why? The operation of the party abroad thus remains an unchartered territory. Here, we look at the party abroad and its potential in light of political parties' needs and wants. We do that from a practical and application point of view. In this regard, the advice to be found in this discussion paper is born out of the practitioners' experience and academic knowledge of domestic party competition and its extension to operations abroad.

The relevance of this research comes as a result of the simultaneous working of a number of mechanisms and events. Recent elections around the world have called attention to the role and power of the vote of those citizens residing abroad - consider the role of German and Dutch Turks in Turkish national elections, which recently brought about international debate (reference). Or the fact that some countries in Europe - like Ireland, for example do not allow their foreign residing nationals to vote for national elections. At the same time, data from IDEA's International Handbook on Voting from Abroad (Ellis et al., 2007) shows that 115 states in the world have some provisions for voting from abroad, and a significant wave of legalization of the voting from abroad among European states can be seen after the 1970 (for detail, see figure 1 ).

Moreover, the scholarly debate on 'transnational voting rights' (Caramani and Grotz, 2015), and the notion of the 'party abroad' in general have started attracting more interest to this topical issue. Most recently, President Macron's proposal for transnational European Parliament lists, which was argued for as an attempt to make the EU institutions more supranational rather than intergovernmental and ultimately attempt to offer a more direct link between citizens and political representative institutions in Brussels, was turned down by a slim majority (EP News, 2017). Finally, political parties of a number of Western democracies have operated abroad under one form or another for an extended period of time. 


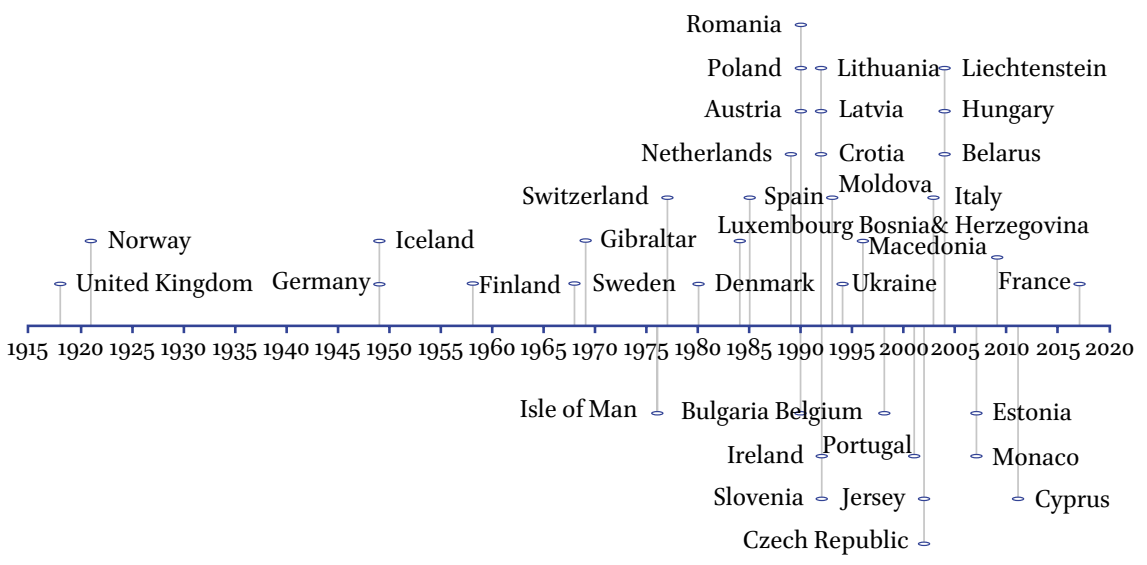

FIGURE 1 Introduction of Voting from Abroad in European Democracies SOURCE: DATA COMES FROM IDEA VOTING FROM ABROAD DATABASE. FIGURE CREATED BY AUTHORS.

\section{$3 \quad$ Typologies and Design Options}

A number of party types have developed over the last century - from cadre and mass parties, to the latest cartel and anti-establishment parties. All these notions of political parties omit one important feature of the 'life' of a political party and that is its function abroad. Extending Duverger's notion (Duverger, 1967) that a party is not a single community, but a collection of communities, however, not restricted to but transcending national borders, is the basis of how we classify the party abroad. The party abroad can thus be understood as any formal or informal establishment, function, or activity of a national political party, outside the borders of the country of origin.

\subsection{Why a Party Abroad?}

An important consideration for any nationally active political party is whether and how to set its operations abroad. In this section we present a number of potential 'design options' that can be used by existing political parties wishing to explore the potential of party operations outside the borders of the country of origin. To choose a fitting strategy, each political party will have to evaluate the constraints which define its functioning. Whether and how a national political party will choose to operate abroad depends first and fore most on its objectives. What are the goals/aims of the given political party? As well, as whose goals per se? The latter will depend a lot on the type of relationship 
political parties have with their members and local chapters. Second, it depends on its resources. How much time and money can a political party allocate for its functions abroad? Third, it depends on an external layer of constraints given by the legal systems of both the country of origin, as well as the host country. Is out-of-country voting allowed, and do diaspora-reserved seats in parliament exist? Are nationally existing political parties allowed to carry political functions abroad and if so, under what conditions or rules? Moreover, are foreign political parties allowed to operate under the host country legal framework and if yes, are there any constraints?

We can identify five potential objectives for the establishing of a party abroad by any nationally active political party (see Figure 2 ).

1 Informal structures - these are loosely created events whose activity is related to a political party and targets its potential supporters abroad, however it is not organized by a party structure per se (since such is nonexistent), nor it is systematically occurring. These types of objectives can be broadly termed 'low cost, intangible/immaterial gain'. Two examples here are social support and political education - many foreign chapters explicitly define their goal as supporting diasporas instead of the party at home. This can either be with the aim of engaging them in debates on what is happening at home, or sometimes of helping their fellow countrymen and women face the challenges of living in a foreign country. This social function can include helping newcomers that do not speak the language of their new country, or that face social exclusion.

2 Networking initiatives - this objective relates to a targeted desire to expand one's network outside of the national borders, whether it is in a country with a large population of people citizens of the country of origin (large diaspora), or whether it is a country that we can term an important international decision and policy-making hub (like Brussels for the

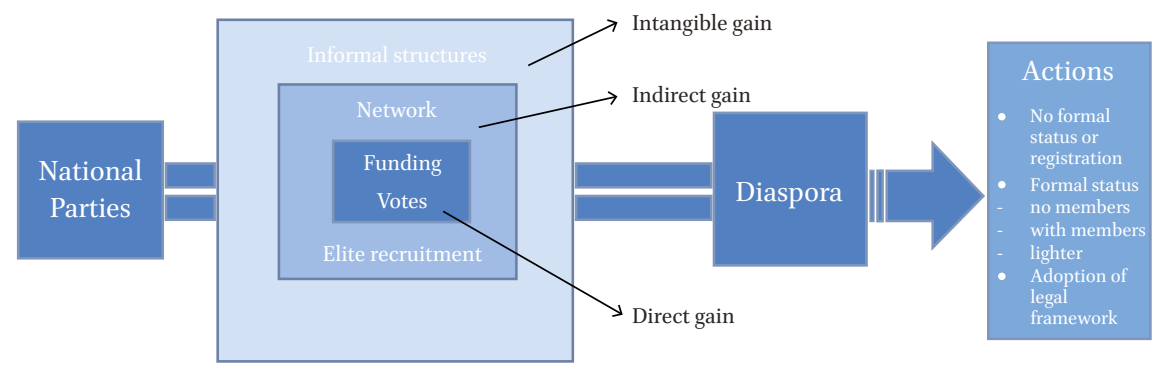

FIGURE 2 Party-diaspora interaction scenarios SOURCE: ORIGINALLY CREATED. 
European Union). The goal of the party here is to broaden its network in order to serve the party's national interests abroad: opening doors for influencing foreign/international policy, policy input for domestic decisionmaking, getting party representatives in international positions. These type of objectives can be broadly termed 'medium cost, indirect gain'. Another activity under networking initiatives, is what we call policy input. An additional type of input is one on policies that affect the diaspora itself, such as on out-of-country voting, or pension-systems for diasporas.

Recruiting candidates - this objective relates to two current trends threatening the existence of political parties across the board - declining membership and lack of quality cadres (this is especially true for many new democracies, where a significant amount of highly-educated and highlyexperienced citizens have left their country of origin and work and reside abroad). The purpose of a party with such an objective would be to expand or fill its candidate lists with highly qualified and internationally educated candidates, which can potentially help the party win more votes, but also get further ahead both nationally and internationally if it succeeds to be part of government. These type of objectives can be broadly termed 'medium cost, indirect gain'.

$4 \quad$ Fundraising - this objective has to do with a political party wanting to generate additional funding either for its operations, for its electoral activities, or both. Given that party funding comes from both public and private sources (in most societies), and that the former is often linked to existing electoral success, generating one's own funds can give a significant advantage to political parties. Therefore, the goal of a party whose objective is to generate additional funds by operating abroad would be to activate the financial support of its citizens residing abroad, by for example pledging donations, support for specific candidate's campaign, or other manner of indirect support - by offering real estate, vehicles, manpower, that can be used for party purposes. This type of objective can be broadly termed 'high cost, direct gain'.

5 Voter mobilisation - this objective is also one with direct effect on the party, and it has to do with a party's goal to increase its electoral success by securing additional votes for itself. Given that most European democracies operate under some sort of a proportional electoral system, where every additional vote counts and thus helps in the overall performance of political parties, connecting operations of the party abroad to voter mobilization is a very likely and natural objective that parties may have. Such an objective, we can broadly term 'high cost, direct gain'. Political parties that are comparatively popular among expat communities, have an extra incentive to mobilise diaspora votes through foreign chapters. 
The typology of objectives discussed above shows that parties' objectives can be allocated to roughly three categories, where each has a different payoff and cost level. This means that various activities and involvement can be judged based on the amount of effort their require (financial and non-financial efforts here are all perceived as 'costs') and the benefit they will result in (different actions can lead to direct or indirect benefit, i.e. something that can be easily seen and measured, like financial contributions or the contribution of time, or not so easily seen and measure, like potential favourable effect on a policy outcome, or the finding of a new potential candidate, who may end up working for the party). The first category is the low cost, intangible gain category. This means that operating through the party abroad by adopting a strategy following such an objective will not cost the national party much, but it will also not have a targeted payoff - such may or may not come, but it cannot be easily predicted. The second category is the one that involves more targeted behaviour, which has a specific goal, but in order to achieve it, it will also require a certain degree of investment (both financial, as well as logistical) medium cost, indirect gain. Engaging in this category then provides that national political parties are prepared to invest time and resources to pursue these objectives with the anticipation that this will result in indirect benefits for it in the future. Here, the potential benefits can be approximated, taking into consideration the type and extent of involvement abroad that the party plans. Finally, the last category high cost, direct gain refers to activities abroad, which are well-planned and carried out with a specific goal in mind - increasing the support for the political party (both financial, as well as in terms of votes). This is the category, in which if political parties engage, they will be prepared to make the largest investment, but also collect the largest potential benefit. The amount of gain can be anticipated to a large degree when basic statistics on amount of investment and potential target group are taken into account.

\subsection{Organizational Models of the Party Abroad}

In this sub-section, we focus on the types of organizational structures that the party abroad can take (see Table $\mathbf{1}$ for summary). This is based on a number of criteria. First, we look at the extent to which the organization of the party abroad is established based on formal rules and procedures or not, and then we look at the extent to which there is a link between the organization of the party abroad and the national party. With these broad divisions in mind, our typology consists of 3 main types of party abroad organizations - informal organization, formal organization without many rights vis-à-vis the national party body, and formal organization with rights toward the national party. Each of these types, as well as the manner in which their establishment and functioning is conceived, are described below. 


\section{Level of organization}

\begin{tabular}{llll}
\hline \multirow{2}{*}{ Link to national party } & & Low & High \\
& Weak & Informal & Formal, without rights \\
& Strong & - & Formal, with rights \\
\hline
\end{tabular}

SOURCE: ORIGINALLY CREATED.

- The informal party abroad: this type of party abroad organization is a loose and most often not systematically structured. It therefore does not consist of a formal organization, building, membership requirements, regular meetings and events, but it is rather run by volunteers, and events are planned on a need-by-need basis. The implications of having such a party abroad structure are that it has low setting-up costs, it is flexible and responsive to current needs and events, and it usually involves a number of devoted to the party ideals and ideas people, who give up their time to render the service necessary. The activities of such a party abroad organization involves informal get-togethers, ad-hoc fundraisers, facilitation of electoral processes abroad, mainly through the supply of information and a connection possibility with the national-party (travelling national party members would often contact or be invited by the informal party abroad, which can organize an event around the politician's visit, by their own initiative or if asked; it can also serve for providing connection/contacts to citizens who may wish to establish a connection with politicians of the said party back in the country of origin).

- The formal party abroad

- The formal party abroad without influence and obligations: This type of a party abroad is formally registered and connected to the national party. As such, there is structure to its organization and activities, responsibilities are allocated among volunteer or paid staff, and frequent contacts with the national party are established. This type of party abroad organization, however, is not financed by or financially obliged to the national party. There is no formal party membership, nor membership fees. Such a party abroad organization would have a high setting-up costs, but would still retain some of the flexibility and responsiveness of the informal party abroad organization. It has the potential to have stronger influence on citizens living abroad and their connection to the domestic political process, due to its formal links with the national party organization. This 
party structure does not take official part in the national party's chosen political paths, nor has voting rights on internal party affairs.

- The formal party abroad with influence and obligations: This type of party abroad is formally registered and connected to the national party. The connection here is more complex than the one just described above, due to the formalization of membership, the collection of membership fees, and the potential influence over the party's domestic policies. This organization has members and, depending on the national model (federal vs. unitary) it may be required to pay all or part of the collected membership fees to the national party. It keeps close ties to the national political party. It has the potential to influence national party politics by manner of sending opinions, declarations, or in some case having its own delegate in the party's national structures. The implications for this type of party abroad model are that it is a high-cost, high pay-out model of organizing the party abroad, where the organization has the resources and the potential to (formally) reach the diaspora community residing abroad, to engage and help them take part in the national political process, as well as to, perhaps, influence the national party's direction of development.

\subsection{Legal Framework of the Party Abroad: A Conceptual Framework}

Thus far, most countries do not have explicit regulation for political parties abroad. Yet, the increasing evidence of movement of people, the number of parties already operating abroad, as well as a number of international conflict due to the campaigning on foreign land, suggest that we are in dire need of extending existing party regulation for national activity, to that of international activity as well. This subsection theoretically develops such legal frameworks, which could guide, as well as streamline and constrain, the activities of political parties wishing to operate abroad. Given that the party abroad links both a nationally operating political party (whether the relationship is formal or informal) with the international political reality of a foreign (host) country, it can be conceived as needing to function within the legal boundaries of both the country of origin, as well as the host country. Below, we discuss the main points of legal consideration, which based on rules for national competition, political parties wishing to operate abroad, may encounter.

- Legal framework pertaining to the country of origin: The first distinction that can be made is between countries which regulate their political parties' foreign activity and those that do not. If a country chooses to regulate its political parties' functions abroad, there are a number of legal rules that may govern the conduct of political parties abroad. These include eligibility and establishment rules, organizational rules, membership rules, funding 
rules, rights and responsibility toward the national-party rules, right of representation, functions rules.

- Eligibility and establishment rules - such rules pertain to the regulations, which describe the conditions under which national political parties can operate abroad. Potential different scenarios can be that all nationally registered political parties are free to operate outside the geographic borders of the country of origin, or that the rule is applied with a certain level of restriction (only political parties that stand for national and European elections, only political parties that have received at least a certain percent of the national vote, or only nationally represented political parties). An example can be found in the US, where non-registered chapters of the parties, set-up in individual countries but not registered with the Federal Electoral Commission are forbidden to campaign, and are only allowed to conduct 'bring out the vote'-campaigns.

- Organizational rules - these are any rules regarding how the political abroad can or must organize itself. There are two main types of organization that may be legislated in the law - formal and informal organization. If political parties abroad are by law to have informal status (not formally registered as national parties), the law will also discuss all aspects of which such organization will not need to abide by - such as membership requirements, membership dues, office, regular meetings and outcomes, etc. Alternatively, in order to function outside the national borders, political parties may be required to have a formal organization. This would in first instance require registration, in one of or both the host country and the country of origin. Furthermore, the formal organization requirement, can split into two sub-types of party organization, where one has also a membership requirement, as well as rights to influence the national party by, for example, sending representatives to its internal party congresses, while the other, can have a formal structure without the requirement of members, as well as without the right to influence the national political party. Another point of legal matter is the (public) funding of such party organizations abroad. Funding can be attached either to membership numbers, or vote numbers, or simply to the amount of population (the diaspora) that such organization is expected to serve. Below is a list of organizational rules and the extent to which we observe them in countries who have parties that already operate abroad.

- Membership rules - rules explaining whether and to what extent the party abroad is obliged to seek formal members and collect fees from them.

- Funding rules - rules about how the party abroad can fund itself. 
- Rights and responsibilities rules - rules about the rights and responsibilities the party abroad has vis-à-vis the national party. These in essence define the 'power' relationship between the two. Rules in this category are related to the right to influence internal party democracy as well as the party ideology and political direction in the future.

- Representation rules - these are rules, which state whether and to what extent the party abroad can participate in internal party matters, such as the national party congress, party committees, and the like.

- Function rules - these rules would lay down the reasons for setting up a party abroad, if such are legislated. They can be very liberal and basically state that the function is to be determined by the leaders of the party abroad organization, or they may restrict the party abroad functions to concrete tasks that serve the national party's interest, for example, voter mobilization, fundraising, candidate supply, etc.

Such provisions can be typically included in national legislation that establishes the rules on the existence and operation of political parties. In most countries, this would mean the Party Law. The Serbian Party Law is one of the few Party Laws in Europe that makes references to activities of political parties abroad (Serbian Party Law 2009, Art. 14, 23, 33, 37) and legally allows membership and the formation of alliances in the country and abroad, as long as the goal is not the destabilization of the territorial entity of the Republic of Serbia. Most European Party Laws make use of the term 'abroad' in reference to allowing or disallowing funding from foreign entities. Alternatively, the issue of the party abroad may be addressed within individual party statutes, where political parties decide how to 'regulate' their own activity abroad.

- Legal framework pertaining to the host country: Similar to the legal framework within the country of origin, the first distinction that can be made is between host countries which regulate the activity of political parties from abroad and those that do not. If a country regulates its political parties from abroad, there are a number of legal rules that may govern their conduct in the host country. These include the right of establishment and operation, and rules about the type of operation.

- Right of establishment \& operation - these are rules from the host country about the establishment and operation of foreign political parties within their national boundaries. Such may be allowed, allowed with restrictions, or not allowed. Slovenia is an example of a country, whose Party Law explicitly states that a party whose office is registered abroad is not allowed to pursue its activities in the Republic of Slovenia (Slovenian Party Law 2007, Art. 3). 
- Type of operation - these are rules that relate to the type of operations foreign political parties are allowed to carry out in the host country. They can include, but are not limited to regular meetings, vote mobilization and public campaigning, fundraising events, public speeches.

\subsection{Decision-Making Model: Shall Parties Engage Abroad?}

National political parties which are considering whether and in what manner to operate abroad need to start their decision-making process by delineating their goals and objectives and by collecting information on the size and type of diaspora that they are facing. The latter will help them evaluate the potential impact that a specific diaspora community may have on their party if they decide to engage with it and can result in choosing target countries. When studying the diaspora and its potential impact on the political party, parties need to know three things: how large is the diaspora community, what is its level of homogeneity (age, education level, income), and what is its level of political engagement (both in the country of origin and the host country). The countries, from which political parties can have the highest impact if they engage with a party abroad, are those with a large and homogeneous diaspora. Medium impact can be achieved in countries with small but homogeneous diaspora or large and heterogeneous diaspora if the diaspora groups are politically active. The final option is a small heterogeneous diaspora, in which case regardless of the level of its political activity, the recommendation is not to engage (Table 2 illustrates these options).

In order to make a decision and choose a strategy it wants to follow, a political party needs to consider its objectives and goals vis-à-vis the type of diaspora

TABLE 2 Decision-making model based on types of diaspora

\section{Diaspora homogeneity}

\begin{tabular}{clll}
\hline Diaspora Size & Low & $\begin{array}{l}\text { Low } \\
\text { Small \& heterogeneous } \\
\text { (advice: create }\end{array}$ & $\begin{array}{l}\text { High } \\
\text { Small \& homogeneous } \\
\text { (advice: deepen }\end{array}$ \\
awareness) & $\begin{array}{l}\text { awareness) } \\
\text { High } \\
\end{array}$ & $\begin{array}{l}\text { Large \& heterogeneous } \\
\text { (advice: deepen } \\
\text { awareness) }\end{array}$ & $\begin{array}{l}\text { Large \& homogeneous } \\
\text { (advice: target } \\
\text { campaigning) }\end{array}$ \\
\end{tabular}

SOURCE: ORIGINALLY CREATED. 


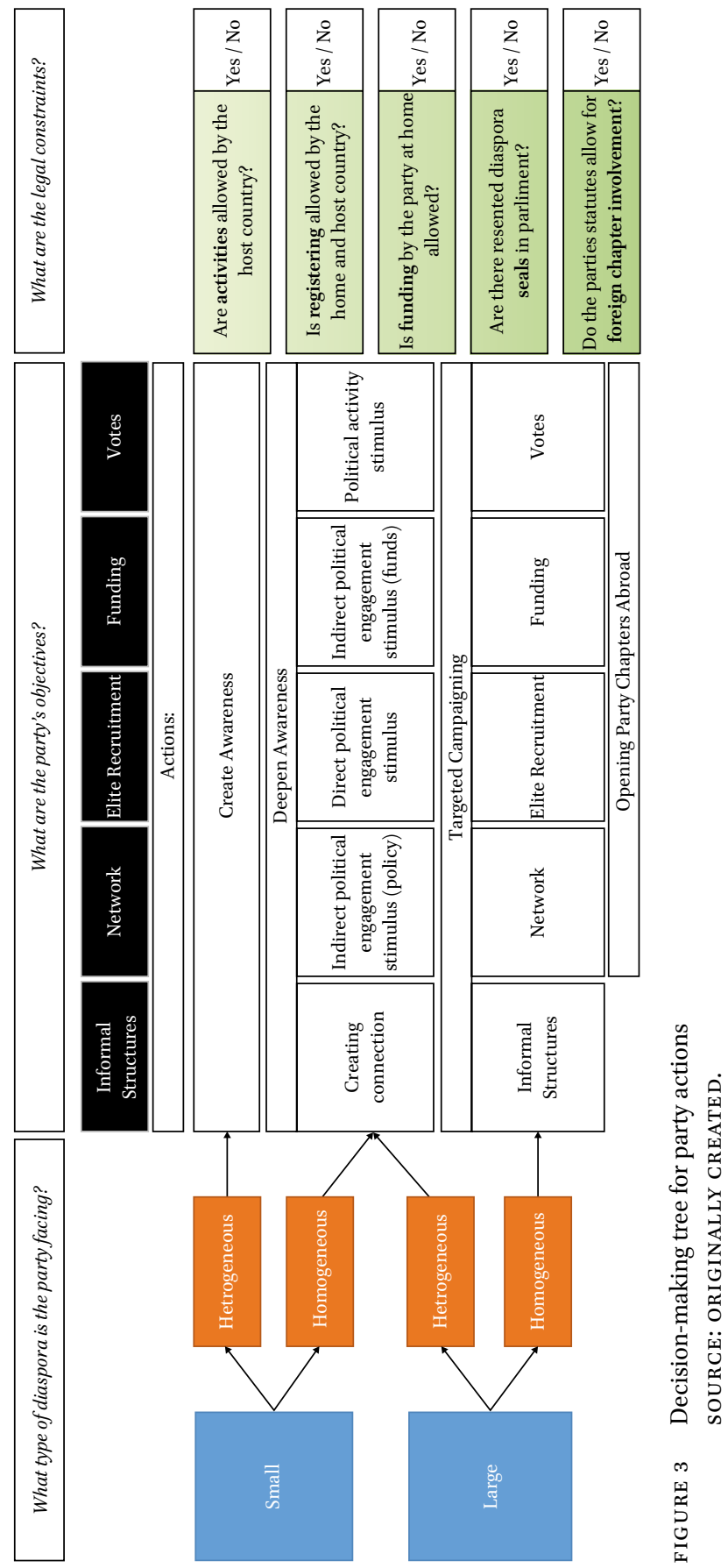


it is facing. Figure 3 provides a visualization of potential strategies a party may choose to follow. Parties willing to explore the possibilities of politically engaging abroad need to start at the top right part of the decision-making tree by defining their objective - to stimulate informal structures, to establish a network, to recruit new elite members, to raise funds, or to collect votes. The next step is to locate the type of diaspora in the given country, as well as the level of political activity of the diaspora group - small or large and heterogeneous or homogeneous. The level of (in)activity is not considered as a constraint in the decision-making, as in general political parties see this as a stimulus, rather than a hurdle because thus-far-inactive diaspora presents them a higher payoff, if they manage to engage them. Based on all these conditions, parties can then follow the tree to the advised strategy to follow. ${ }^{1}$

\section{$4 \quad$ Empirical Evidence}

To best address the link between theory and practice, we surveyed practitioners - political party organizations - about the nature of the activity of their party, as well as 'best practices' of their party's operations abroad. A number of accounts of political parties from different geographical regions, as well as various levels of democratic development, are summarized below in the form of short case studies. We interviewed political representatives from 6 different political parties, coming from Germany, France, Spain, Turkey, Ukraine and the USA. In a semi-structured interview-style, representatives shared their party's experiences about engaging with their voters abroad. The cases were chosen to reflect a variety of geographic location, ideological diversity of political parties, a mix of established and younger democracies, and countries with different types of diaspora.

\subsection{Germany - The Christian Democratic Union}

The CDU is a Christian Democratic, liberal conservative, political party, which was founded in 1945. Its current leader, and Germany's Chancellor, is Angela Merkel. The party stands out for a number of reasons, not the least that it has occupied the chancellor's office for 48 years in Germany's recent political

1 The decision of a political party of whether or not to operate abroad, may differ depending on a number of contextual factors such as the electoral system type, the culture of 'connectedness', the economic development, the level of democracy and party system institutionalization. 
history (Deutsche Welle, 2017). In 2016, its membership was recorded as 431920 (Niedermayer, 2017).

How does the CDU Operate Abroad?

There is one formal party group abroad - CDU Brussels - which has been created to represent CDU's pro-European stance in Brussels. The CDU-Brussels is obliged to abide by the same rules as the national party, meaning that it has to collect membership fees, a portion of which need to go back to the national party. CDU-Brussels does not receive direct financial support from the main party, since they are treated as 'local level party'. CDU-Brussels is characterized with a very high level of organization, which allows the national party to stay informed about who works there and who to contact. The CDU-Brussels has the right to:

- Send one delegate to the $1001 \mathrm{CDU}$ delegates who meet regularly to discuss party matters ( 1 is always reserved for CDU-Brussels regardless of how many members the party there has)

- Can send drafts on various topics they deem important to the central party

- Can send resolutions about specific actions to be taken to the central party There is another, informal, type of organization, which has informal ties with the CDU and these types of organizations are called Circles of Friends. These organizations exist in many places, but they are under no legal obligations, the people working closely with them or connected to them do not have to be members of the party, the organization does not have to collect membership fees, nor pay dues to the national party. The connections between these organizations and the national party are less formalized. Yet, around federal and European Parliament elections the CDU sends some information about the election, about the campaign, about how to register and vote, sometimes video interviews with certain political candidates.

Why Organize in Such Manner?

A major reason behind having only one formal party abroad organization is related to the legal obligations that this party chapter has and to the inability of the CDU-national of monitoring the activity of organizations spread in all corners of the world. A further complication is the fact that the Germans abroad are a very heterogeneous group which may not have much in common, other than being German citizens.

What are the Main Goals and Legal Arrangements in Operating Abroad? The main goal is to keep German citizens living abroad close to the party (voter mobilization), as well as to influence policy at the European level (EU policy). 
For the operations of the party abroad, a main legal obligation is the financial one. This is one of the main reasons for having only one formal party abroad chapter. The party abroad has to function in the same manner as other federal chapters, they have to collect membership fees and pay a portion of them into the national party. Voting from abroad is relatively easy. The main legal obstacle here is proving one's connection with Germany if residing outside the country for a period longer than 6 months.

\subsection{Ukraine - The Petro Poroshenko Bloc}

The Petro Poroshenko Bloc ( $\mathrm{PPB})$ is a center-right, liberal conservative political party, recently established in 2014 around its leader, and Ukraine's current president, Petro Poroshenko. The party is pro-European and stands for Ukraine's west-ward development in political and economic terms. The party has recorded membership of 37922 members in 2017 (Ukrinform.net). ${ }^{2}$

How does the Рр в Operate Abroad?

The Petro Poroshenko Bloc currently does not operate abroad. Its leadership does, however, consider doing this in the near future given the large number of Ukrainian citizens living abroad - numbering over a million only in neighboring Poland (Puto 2017). ${ }^{3}$

\section{Why Organize in Such Manner?}

There are two main reasons for the lack of activity of the party abroad - low capacity and low priority. The first refers primarily to lack of funding and human capacity for foreign activity, and to some extent lack of active knowledge on how to do it. The second reason has to do with Ukraine's current state of political affairs, in which the РРВ is a key player in strengthening the country and setting it on a path of political and economic recovery, which puts the priority of the party on the domestic arena. There is an active third-fourth generation Ukrainian diaspora in Canada and other parts of the world, who keep connected to the party and support the democratic change within their ancestral country. РР В keeps in touch with them and schedules meetings of the party's high-level officials when they travel internationally. The organization of such events is done via the Ukrainian embassies or via the leaders of the diaspora communities abroad.

2 https://www.ukrinform.net/rubric-polytics/2398730-petro-poroshenko-blocs-membership -grew-by-one-third-in-2017.html.

3 Furthermore, according to Chmielewska et al. (2017), Ukrainian migrants in Poland work longer work weeks and transfer the majority of the earnings to their families in Ukraine - for 2015, the estimate size of the remittances was $€$ 1.1billion. 
What are the Main Goals and Legal Arrangements in Operating Abroad? The two main goals for keeping ties with the Ukrainian diaspora are political influence and mobilizing foreign investment/setting up businesses by diasporas in Ukraine. Most of the systemic obstacles are lack of resources to organize out-of-country voting, following budgetary cuts for embassies, and lack of information on how especially the first-generation Ukrainian diaspora is organized in various places.

\subsection{Spain-Podemos}

Podemos is a recently founded Spanish left-wing political party, which operates since 2014. The party quickly gained popularity with its anti-establishment stances and is currently the second largest party in Spain judged by its membership, which is currently over half a million people (Podemus website). ${ }^{4}$ Podemos is relatively popular among youth voters and those abroad.

\section{How does Podemos Operate Abroad?}

Podemos has two types of structures abroad - circles and areas. The former, sometimes called assemblies, are locally funded chapters and enumerate about 30 globally. The latter, are working groups that work across countries on preparing policy solutions for diaspora interests, which are shared with the central party. Once per year there is the Podemos Global Assembly, which is funded by the central party. Podemos has 11000 members abroad and believes it has strong potential among the 2.5 million Spaniards abroad, especially those that have fled youth-unemployment. Podemos diaspora members have access to the central party as all other members do, via an online platform called Agora Voting, and they may make financial donations to the party also online.

\section{Why Organize in Such Manner?}

Podemos strives toward a decentralized decision-making model that puts the emphasis on addressing diaspora concerns, and where the party works toward 'local ownership of local problems'. Of Spain's 2.5 million citizens living abroad, Podemos believes many sympathise with their party. However, only 5 percent cast their ballots for national elections, which Podemos claims is partly due to the difficult out-of-country voting process. Moreover, many Spaniards choose not to register with Spanish consulates when moving abroad, as they stand to

4 Podemus party website, available at https://participa.podemos.infso/es (accessed June, 2018). 506,817 members reported. 
lose their health care insurance, thus barring them from voting from abroad. This has led the party to actively campaign for easier out-of-country voting procedures. The central party pays for one salaried staff in Berlin that helps to coordinate between circles and areas, and elected representatives in Brussels, Madrid and elsewhere. Most people who are involved, however, do so on voluntary basis. When officials of the national party travel, they normally establish links with Podemos Circles. Podemos Circles meet online every three months, while the elected representative of Podemos Abroad travels to Spain to meet other party officials 4 times per year.

What are the Main Goals and Legal Arrangements in Operating Abroad? Podemos abroad has its main goal to serve the Spanish diaspora, and it tries to affect Spanish policy making toward Spaniards abroad, while at the same time carrying out social mobilization and support function for Spanish migrants (for example, providing language learning aid even to non-members). Another goal is to influence the Spanish government to open reserved parliamentary seats for voters abroad. The main legal obstacles have to do with Spanish rules, which make the life of Spaniards abroad and their political participation back home, harder. Two examples include the earlier mentioned out-of-country voting procedures, and a lack of clarity on the legality of using state funding from the central level to fund foreign chapters.

\subsection{United States - Democrats Abroad}

Democrats Abroad (DA) is the organization of the Democratic Party for American living abroad. The Democratic Party is one of the two main parties in American Politics and it has been founded in 1828 .

How does the DA Operate Abroad?

It has the same status vis-à-vis the national party as every of the 50 states, D.C. Puerto Rico and the overseas territories. As a result, it has 8 seats on the Democratic National Committee (DNC), which meets annually and decides on internal and external matters. The party has members in 190 countries and 43 country committees. It is self-financed through donations only of American citizens.

Why Organize in Such Manner?

The party is highly organized and represents the 9 million Americans living abroad (6.7 million of whom are allowed to vote). Its status as a 'state' gives the DA the opportunity to an equal seat at the negotiation table in D.C. It is concerned primarily with raising visibility and awareness of the issues of 
Americans abroad in Washington. Its decentralized manner helps to live in the American spirit and help locally, while at the same time work toward a common goal of furthering the Democratic representation in Congress. Fundraising happens through events, letters, auctioning of people's personal offerings (like a week in 'my vacation home in Spain'). The DNC provides indirect help, such as supplying telephones. The volunteers working for the DA, try to establish a culture in which American politicians travelling abroad would contact the local DA chapter, when being on business in a country where a chapter is located.

\section{What are the Main Goals and Legal Arrangements in Operating Abroad?}

The Democrats Abroad have a number of goals related to helping their party win domestically, but also to influence policy to help its co-nationals abroad. A primary goal is to stimulate as many ballots as possible to be sent back to the US and in this way supporting the party and its electoral success. This is necessary due to the fact that voting from abroad for the US is personal and happens by regular post, which often precludes many citizens from voting as they find it cumbersome, as well as unreliable when residing in remote places. Having own influence within the party; influence is stronger when the number of votes from abroad 'tip the balance'. For example, Al Franklin (Senator from Minnesota) was elected on a very 'close' vote, with only 2000 votes making the difference; at that particular instance the foreign vote was 3000 , therefore the DA could make the argument that their vote matters. Another goal is to create visibility and awareness (letting politicians in the US be reminded about the 9 million Americans living abroad and their issues). Finally, the DA aim at lobbying. The DA works for its constituents and tries to resolve the many, often legal, issues for American citizens living abroad; examples include the Foreign Account Tax Compliance Act; medical insurance (Obamacare) when US citizens who do not have an American Insurance would get fined; the DA lobbying and proposes 'easy fixes', which can be often implemented by legal exemptions.

The most notable obstacle for DA's operations abroad is that under the US Election Law, it is not allowed to accept any money in the form of donation from anyone who is not an American citizen or a green-card holder. Furthermore, how local chapters keep track of their funds is cumbersome, as they have to keep local and international funds separately. As a non-registered body with the Federal Election Commission (FEC), individual country chapters are not allowed to advertise in a local magazine. They can only raise awareness and promote voting, but they cannot promote a candidate. In addition, they choose to stay out of the politics of the hosting country. Voting from abroad 
can be difficult. It happens based on the last US residential address of the voter. The DA organization has since 2002 created a global website (votefromabroad. org), which started operating in 2004. The aim of the website is to serve the Americans abroad and to help them in all questions related to voting from abroad.

\subsection{France - La République En Marche!}

La République En Marche (LREM) is a centrist political party with proEuropean liberal views, which aims at modernizing France and work toward better European Integration. It was founded by the current French President, Emanuel Macron, in April 2016. At the moment it is not affiliated with any European Party. Despite its newness, the party has done very well in recent presidential and parliamentary elections, currently leading both institutions.

How does LREM Operate Abroad?

There are an estimated 2.5-2.6 million French citizens residing abroad. LREM has 28,000 members in 110 countries. Its operations abroad are organized in 16 zones and 450 local committees (comités locaux). The Benelux is one of sixteen zones and it has 33 local committees within it. Globally, Brussels is the biggest local committee, with 700 members. The Benelux zone helps the local committees develop themselves and provides support. Activities that the LREM organizes range from internal workshops with members to external events such as breakfast meetings with MPs, market events and the like. Members of LREM do not pay fees. Financial support comes from public funding and is provided from the national party to the LREM zones, and is then further redistributed by the zone leader. The zones and committees of the LREM abroad are largely independent, yet the headquarters of the party provide also guidance to the LREM zones. This happens through the provision of documents for how to hold and organise marches, as well as administrative and legal support. The LREM headquarters in Paris have a team to help LREM zones and committees abroad. There are two members on the LREM executive committee responsible for the French abroad: one specifically for the foreign chapters, the other is the international affairs executive. The Benelux leader of the party has monthly calls with these members, which shows a close connection between the national party and the party abroad.

\section{Why Organize in Such Manner?}

The structure of the party abroad - with zones and committees - reflects the decentralised nature of LREM. This decentralised nature is also illustrated by the fact that LREM members do not have to be French, for example, the Brussels committee includes Belgian citizens. However, the issues that the 
party deals with are French issues. France has 11 reserved seats in its National Assembly for French diaspora abroad, including one for the Benelux. Whereas the elected representative for the Benelux represents French citizens in the Benelux broadly and regardless of party affiliation, the LREM abroad represents LREM-members in the Benelux more narrowly.

What are the Main Goals and Legal Arrangements in Operating Abroad? The main objectives of the LREM abroad are creating awareness among French citizens abroad about what LREM is doing to improve their lives; making France 'shine around the world'; using the diaspora's input for policies at home (for instance, LREM Brussels sends information about the EU to help the party discuss EU-issues in French villages, as part of the Grande Marche pour l'Europe, consultative meetings that President Macron has initiated in France and elsewhere); aims to make French citizens abroad aware that they can vote. Voting from abroad is not difficult, but there are certain barriers. LREM therefore argues for the re-introduction of E-voting, which was also a policy proposal in Macron's election manifesto. LREM abroad also stimulates French citizens to vote at an individual level. LREM abroad does not aim to open doors or to network within the EU for France or for visiting LREM Ministers. That role lies with the French MP Pieyre-Alexandre Anglade, who is the elected representative for the Benelux region in France's National Assembly. He is the formal representative of the French diaspora in the Benelux. In many European countries, there are legal impediments for LREM to campaign or to even register. For instance, due to legal restrictions of foreign political parties to campaign or be registered, LREM is not allowed to campaign in Luxemburg or Poland.

\subsection{Turkey-Republican People's Party}

The Republican People's Party (CHP) is the oldest political party in Turkey. It has social democratic ideology and is currently the main opposition party in Turkey. It is a member of the Socialist International and an associated member of the Party of the European Socialists.

\section{How does CHP Operate Abroad?}

CHP has at least 27 chapters outside Turkey, including in the EU, Canada, Australia, and Western Balkans. In the Netherlands, there are approximately 260,000 Turkish citizens who are entitled to vote. CHP Netherlands was established in 2013 as an association. The CHP association board formally consists of 22 members: 12 board members, 5 members of the oversight body, and 5 members of the disciplinary board. It has 800 regular members, who pay a financial contribution, but are not members of the CHP party in Turkey, since there is no 
formal relationship between the CHP Netherlands and CHP Turkey. Informally, however, the two organizations are linked. For example, two representatives of foreign chapters (the one in Berlin and the one in the Netherlands) have been placed on the party list of candidates for the upcoming national parliamentary elections. Furthermore, the foreign CHP chapters were invited to nominate a member for the Board of CHP Turkey, which was taken up by the Strasbourg representative. The chairpersons of the 27 foreign chapters meet with CHP Turkey regularly (more than twice a year) for 2-day gatherings. In addition, the chapters for Germany, Belgium and the Netherlands meet regularly to organise joint activities and create common positions.

\section{Why Organize in Such Manner?}

One of the reasons for organizing in such a way is the party's understanding that international law does not allow political parties to establish themselves outside their country-of-origin. This is why CHP Netherlands exists as an association, rather than a foreign branch of a political party. This also relates to the organization's informal links with the main party.

What are the Main Goals and Legal Arrangements in Operating Abroad? The main goal of the CHP party abroad is to be a representative of the interests of Turks abroad. Related to this, the main party, CHP-Turkey, is calling for reserved diaspora seats in parliament, striving to make Turks abroad the 82nd constituency in parliament. A similar move is pursued also by the ruling AK Party. CHP Netherlands has strong contacts with various social-democratic parties in the Netherlands, however, other chapters face legal obstacles for organising their activities during campaign time. For example, in Germany, it is illegal to campaign 3 months to an election.

\section{5}

\section{Conclusion}

In this article, we engage with the understudied operation of political parties abroad. The 'party abroad' as a type and development of the functions of political parties is still new, yet the current migration trends around the world make the attention to this phenomenon a must. To unravel the notion of the 'party abroad', we connect the observable developments of on the one hand, increasing diaspora groups around the world, with, on the other hand, a rising number of international clashes related to political campaigning on foreign land and develop a typology of the party abroad, as well as a legal theoretical framework, under which parties abroad can function and exist more systematically. 
This suggested theoretical legal framework can be implemented within the Legal Regulations of Political Parties, which odihR (OSCE) publishes and distributes to all its member-states annually. The article also provides empirical evidence of six political parties, which currently operate abroad. The political parties we surveyed vary significantly in terms of their institutionalization, experience, finances, as well as on the level of democratic development in their home countries, and the size and type of diaspora they are facing abroad. A significant difference among the parties we interviewed was their funding model from funded through national public funding to being fully dependent to acquire their own funding. Despite their varied backgrounds, all representatives with whom we spoke emphasize the need and opportunity to operate abroad (in terms of representation, but also in terms of electoral size), but also point to the fact that there is no established manner of conduct for most of them, neither at their home countries, nor in the countries they wish to operate. All relations with the 'mother' party are party-based and can vary from strictly structured to very loose. All this evidence suggests that given the need for operating abroad, parties will benefit from more structured rules for existence and operation - similar to nationally operating parties - which, in turn, can lead to concrete relationships of the party abroad in host countries, but can also open the opportunity for host countries to begin to represent diaspora voters in what is now their new-homeland. The research presented here adds to the large body of extant literature on political parties and party system development, and it intends to open up a societal, as well as scholarly debate, on what and how to do with the representation of people who live outside their original country of birth.

\section{References}

van Biezen, I. and Borz, G. (2012) 'Models of party democracy: Patterns of party regulation in post-war European constitutions', European Political Science Review, 4(3), pp. 327-359. doi: 10.1017/S1755773911000294.

Burnell, P. and Gerrits, A. (2010) 'Promoting party politics in emerging democracies', Democratization, 17(6), pp. 1065-1084. doi: 10.1080/13510347.2010.520548.

Caramani, D. and Grotz, F. (2015) 'Beyond citizenship and residence? Exploring the extension of voting rights in the age of globalization', Democratization. Taylor \& Francis, 22(5), pp. 799-819. doi: 10.1080/13510347.2014.981668.

Casal Bértoa, F., Piccio, D. R. and Rashkova, E. R. (2014) 'Party laws in comparative perspective', in Regulating Political Parties: European Democracies in Comparative Perspectives, pp. 119-148. 
Chmielewska, I., Dobroczek, G. and Puzynkiewicz, J. (2017) A new wave of Ukrainian migration to Poland, Financialobserver.eu. Available at: https://financialobserver.eu/ poland/a-new-wave-of-ukrainian-migration-to-poland/ (Accessed: 18 July 2018).

Deutsche Welle (2017) What you need to know about Angela Merkel's CDU, Deutsche Welle. Available at: https://www.dw.com/en/what-you-need-to-know-about-angela -merkels-cdu/a-3915036o (Accessed: 18 July 2018).

Duverger, M. (1967) Political Parties: Their Organization and Activity in the Modern State. Metheun.

Ellis, A. et al. (2007) Voting from Abroad - The International IDEA Handbook. Stockholm: International IDEA.

Hobbes, Thomas, (1968). Leviathan. Baltimore: Penguin Books.

Katz, D. and Mair, P. (1995) 'Changing Models of Party Organization and Party Democracy: The Emergence of the Cartel Party', Party Politics, 1(1), pp. $5^{-28 .}$

Locke, John. (1948). Second treatise of civil government and a letter concerning toleration. Oxford: B. Blackwell.

Niedermayer, O. (2017) Parteimitglieder in Deutschland: Version 2017 NEU, Arbeitshefte aus dem Otto-Stammer-Zentrum, Nr. 27. Available at: http://www.polsoz.fu-berlin .de/.

Rashkova, E. R. (2015) Electoral Law and Party System Development in Contemporary Central and Eastern Europe: A Database, Electoral Law Depository. Available at: http://www.electorallaw.org/.

United Nations (UN) (2017) International Migration Report 2017. doi:ST/ESA/SER.A/404.

World Bank (2017) Population database. Available at: data.worldbank.org/indicator/ SM.POP.REFG. 